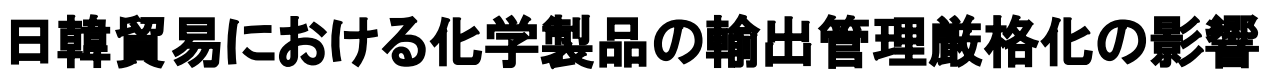

\author{
細江 宣裕
}

Nobuhiro Hosoe

August 2019
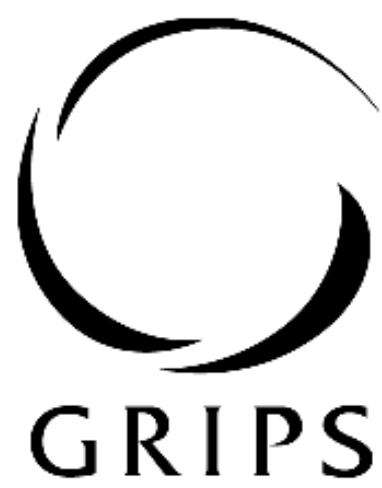

National graduate institute FOR POLICY STUDIES

National Graduate Institute for Policy Studies

7-22-1 Roppongi, Minato-ku,

Tokyo, Japan 106-8677 


\section{日韓貿易における化学製品の輸出管理厳格化の影響}

2019 年 8 月 20 日

政策研究大学院大学

細江宣裕*

概要

経済産業省は 2019 年 7 月に優遇措置として与えられていた韓国への一部化学製品の輸出手続 きの簡素化を取りやめると発表した。これによって、韓国国内の半導体、電子製品の生産や世界 市場への供給が滞ることが懸念されている。本研究では、世界貿易の応用一般均衡モデルを用い、 化学製品に対する一種の輸出税の賦課や、韓国の電子製品産業の生産性の低下が生じた場合を 考えて、その経済的影響をシミュレーション分析によって明らかにする。その結果、生産性が低 下する場合には、電子製品の国際市場や、韓国以外の国々の経済厚生(実質消費の変化額)に対す る影響は全般に小さい。しかし、輸出税が課される形になると、貿易パタンは大きく変化し、日 韓ともに経済厚生に対して同規模の悪影響が出る。ただし、両国間の経済規模の違いが大きいの で、GDP 比で見ると日本が被る損失は、韓国のそれよりもかなり小さい。<smiles>[3H][I][3H]</smiles>

貿易円滑化; 経済統合; 応用一般均衡分析

JEL Classification: F13, F15, F17, C68

*106-8677 東京都港区六本木 7-22-1. E-mail: nhosoe@grips.ac.jp. 


\section{1. 導入}

経済産業省(2019)は 2019 年 7 月に外国為替及び外国貿易法に基づく輸出管理について、2004 年以来、優遇措置として与えられていた韓国への一部化学製品(フッ化ポリイミド、フッ化水素、 レジスト)の輸出手続きの簡素化を取りやめると発表した。これらの化学製品は韓国の半導体、 電子産業における重要な中間投入物であり、韓国は上記 3 製品についてそれぞれ、 $94,92,44 \%$ を 日本からの輸入に依存している(ニューズウィーク日本版(2019), Yang and Park (2019))。日本から のこれらの製品輸出が滞ることで、半導体、電子製品の国内生産が影響を受け、さらには、世界 市場への輸出供給が滞って価格が急騰すると懸念されている。半導体産業はきわめて集中の進 んだ装置産業であり、韓国は DRAM の 75\%、NAND 型フラッシュメモリの 45\%を供給してい る(ニューズウィーク日本版(2019), Yang and Park (2019))。

半導体のようないわゆるハイテク産業は、農業のような伝統産業とはまた違った意味で、貿易 摩擦を引き起こしやすい。1980-90 年代には日米間の貿易摩擦の 1 つとしてスーパーコンピュー タの対米輸出が問題になり、中国からの半導体製品・通信機器を巡っては、2019 年に米国が安 全保障上の問題として米国内企業による利用規制を課した。こうした貿易摩擦の多くは、貿易赤 字を問題視するアメリカを中心として発生したが、日韓間でも、韓国政府からの補助金を受けた として、日本政府が 2006-2009 年にハイニックス製 DRAM に対して相殺関税を課した。

これらの動きは、関税措置であれ非関税措置であれ、また、その理由が安全保障上の動機から くるものであれ政治経済的な動機からくるものであれ、一種の経済統合の巻き戻しとして考元 られるであろう。より大規模には、英国の欧州連合(European Union, EU)離脱や、北米自由貿易協 
定(North American Free Trade Agreement, NAFTA)の再交渉、あるいは、Trans-Pacific Partnership (TPP)協定の批准段階での米国の離脱といったものが挙げられる。こうした経済統合、ないし、 その巻き戻しといった分析には、応用一般均衡(computable general equilibrium, CGE)モデルを中心 とした一般均衡的な世界貿易モデルがしばしば用いられる。川㠃(2017)は米国や英国による地域 経済統合の流れに逆行する選択の影響を分析しているし、Brexit の影響分析についてもさまざま な観点から事前の予測が行われている(たとえば、PwC (2016), Dhingra et al. (2017), Hosoe (2018), Jafari and Britz (2018))。これらはいずれも、経済統合の巻き戻し効果について、各産業の生産や 貿易量、消費者便益といった側面への影響を国別に示しており、政策形成・評価のために有用な 示唆を与えている。

本研究も同様の文脈で、日韓間の貿易障壁の経済的影響について応用一般均衡モデルを用い て測る。もちろん、この分析は両国間の貿易の円滑化を阻害することによる経済効果のみを測る ものであり、経済産業省(2019)が当該政策変更の理由としている、不適切な輸出事例の解消それ 自体がもたらす効果を測っているものではない。ここでは、日本から韓国への化学製品の輸出管 理の厳格化を、輸出税があらたに課されたものと解釈する場合と、手続きの厳格化によって不確 実性や非効率性が高まることで韓国における電子産業の生産性が低下すると解釈する場合の 2 種類を考えて、仮想的なシミュレーションを行う。これによって、日韓両国の生産や経済厚生が どのような影響を受けるか、また、電子産業の世界市場がどのような影響を受けるかを例示する。 ただし、現在考えられている輸出管理の厳格化が、どの程度の貿易非円滑化効果を持つのかは 量的にも質的にも明かではない。そこで仮想的に、前者について $50 \%$ の輸出税率が課されたもの と仮定し、後者については、前者のシミュレーションで得られた電子産業の生産量の減少幅と同 
じだけの生産量の減少をもたらす全要素生産性(total factor productivity, TFP)の低下を仮定してシ ミュレーションを行う。その結果、輸出管理の厳格化の悪影響が TFP の低下をもたらす形で表 れた場合には、韓国の電子製品産業の生産・輸出以外には、経済厚生の損失という観点も含めて 影響は大きくない。より深刻な帰結は、輸出税を課す形で影響が表れた場合である。TFP の低下 がもたらす厚生損失と比べて、日韓両国ともかなり大きな損失を被る。いずれの場合でも、韓国 の電子製品輸出が減ってできた隙間を日本やそのほかの主要生産国からの輸出が埋めて、全体 として国際市場の需給は大きく崩れない。

本稿の構成は以下の通り。つづく第 2 節でシミュレーションに用いる応用一般均衡モデルに 関して説明する。合わせて、そこで用いたデータと、実際の輸出管理の厳格化対象となった化学 製品や半導体産業に関するデータについて確認する。第 3 節で、シミュレーション・シナリオと その結果について説明する。第 4 節で分析の限界と今後の拡張、および、政策的議論を行って結 語とする。

\section{2. モデルとデータ}

\section{1 応用一般均衡モデル}

本研究では、細江ほか(2016)で詳説した一国経済の静学的応用一般均衡モデルを世界貿易モデ ルに拡張したものを用いる。そこでは、日本、韓国と、(日韓以外の)東アジア、東南アジア、NAFTA 地域、EU28 力国、中南米、その他地域の全 8 地域を区分する。産業部門は、焦点となっている 化学産業と電子産業を含む、全 9 部門を考える。各国において、国内生産のために、資本と熟 
練・非熟練労働の 3 種類の生産要素と、種々の中間投入物を利用する。これらの生産技術を表す 生産関数は、簡単化のために、すべて規模に関して収穫一定の生産関数を仮定する。ただし、細 江ほか(2016)とは違って、比較的短期的な影響を考元るために、3つの生産要素のうちの資本に ついては部門間を移動しないものとする。一方、労働については部門間を移動できるものとする 1 。

作られた生産物は、輸出向けの輸出合成財と国内向けの国内財に振り分けられる。この変形の ための生産技術として、変形の弾力性一定(constant elasticity of substitution, CET)の関数を仮定す る。輸出合成財は、さらに、各国向けの輸出財に振り分けられる。一方、各国からの輸入財は、 それらを合成して輸入合成財を作る。この輸入合成財と国内財をさらに合わせて Armington (1969)の合成財を作る。この合成のための生産技術として、代替の弾力性一定(constant elasticity of substitution, CES)型関数を仮定する 2 。この Armington の合成財が、最終的に、家計消費、政府 消費、投資需要、中間投入に用いられる。家計による各財の消費量を Cobb-Douglas 型関数で集

1 ひとたび据え付けられた資本設備をすぐに他部門に移動して利用するようなことは、短期的には難しい と考元られるであろう。資本だけでなく、労働についても同じく部門間を移動できない、という仮定を置 くことが考えられるかもしれない。しかしながら、そのような仮定を置くと(中間投入以外に)調整可能な投 入物がなくなってしまうので、各産業の生産量までもすべて固定されてしまい、本研究で明らかにしたい 生産量や貿易量の変化を示すことができなくなってしまう。

2 代替の弾力性とは、(たとえば輸入財と国内財の間の)相対価格が $1 \%$ 変化したときに、何\%だけ輸入財と 国内財が代替されるかを示す指標である。この值が大きいほど、両者は類似した財であり、少しの価格の 変化で一方が他方に大きく代替される。 
計することで、各国の代表的家計の効用水準を測る。

図 2.1: 世界貿易応用一般均衡モデルの構造

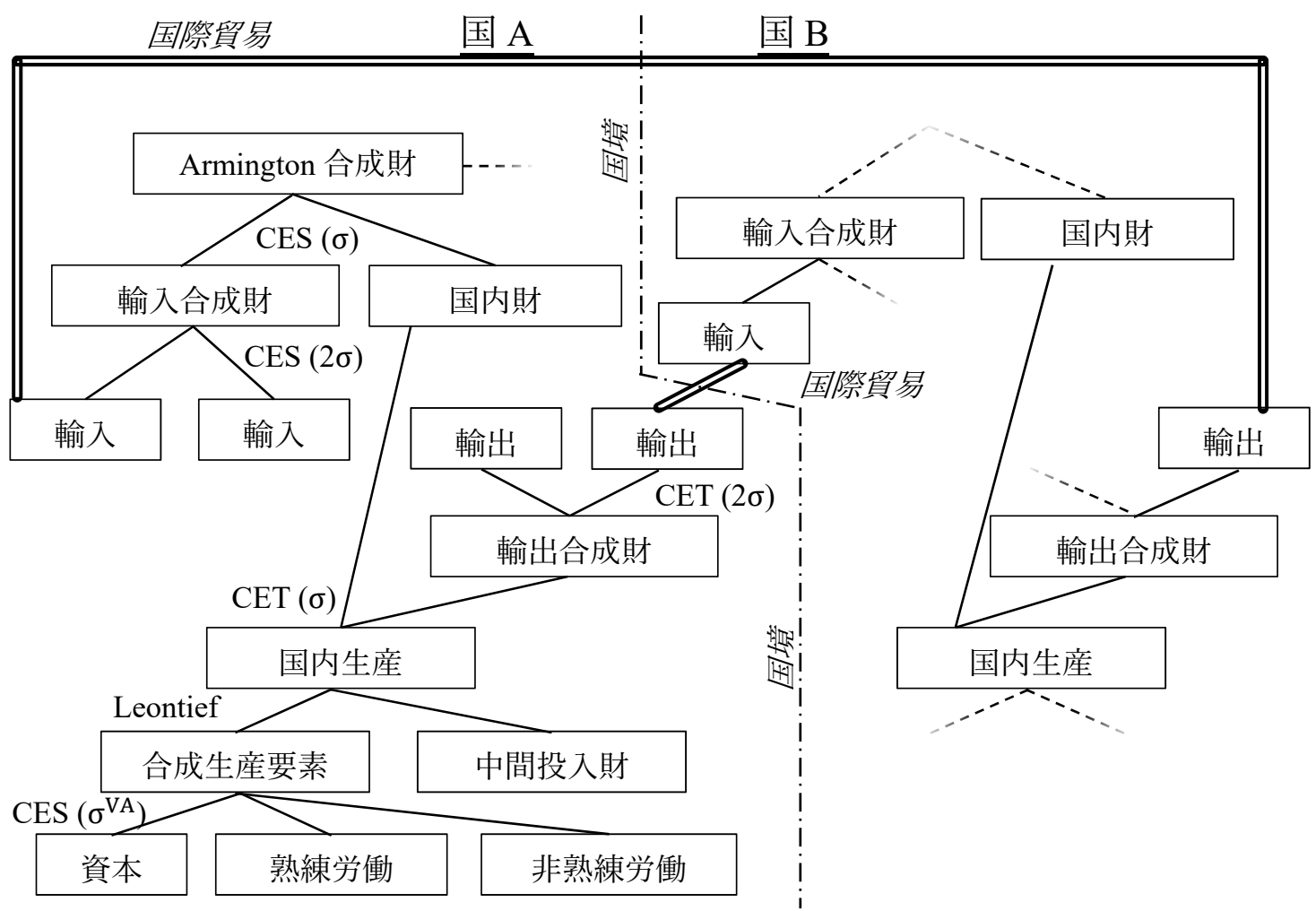

出典: 細江ほか(2016, 図 10.3)を一部改変。

注: 図中では Armingtonの合成財の利用方法を省略している。詳細については、CES/CET 関数等 の説明とともに、細江ほか(2016)参照。

モデルの中で重要な構造は、国内における生産量と投入量の関係を示す生産関数と、外国との 間の相対的な(価格)競争力の差によって輸出・輸入が決まる代替可能性である(Armington (1969))。 すなわち、日本による輸出税の賦課によって韓国の輸入中間財(化学製品)の価格が上昇すれば、 (同種の)国産財が輸入財を代替する。ただし、輸入財の価格上昇だけでなく、より多く投入され ることになる元々割高な国産財のために、全体としてはそれを用いる部門(電子産業)の生産量あ たりの費用が上昇し、国内生産が減少する。また、海外市場においても、外国製品よりも割高に 
なるために輸出が減少するであろう。輸出税の代わりに、電子産業の TFP が低下するという悪 影響が出ると考元る場合でも、類似のことが起こるであろう。すなわち、生産性の低下は、同じ 投入量を維持していたとしても、生産量が減少してしまうことにつながる。このとき生産量あた りの費用が上昇してしまい、同様に生産量の減少や輸出競争力の低下に結びつくであろう。 そのほか主要なモデル上の仮定については以下の通りである。要素市場は各国内で完全雇用 とし、国際的な要素移動はないものとする。経常収支は、その他地域通貨建てで一定であるとす る。ワルラス法則から、各国の非熟練労働を基準財としてその価格を固定する。各財に対する政 府消費需要と投資需要は、それぞれ、総税収と総貯蓄に応じて比例的に決まる。なお、輸出税シ ナリオで追加的に得られる日本から韓国への化学製品輸出に対する輸出税収はほかの税収とと もに政府消費・貯蓄に費やされ、家計への移転等には費やされない。

\section{2 データ}

この応用一般均衡モデルを、GTAP データベース・バージョン 10(基準年 2014 年)の経済・貿 易データと種々の弾力性にキャリブレートして推定する $(H e r t e l(1997))^{3}$ 。しかしながら、GTAP デ ータベースを用いる際には、部門分割に関して問題が発生する。すなわち、経済産業省(2019)に よる輸出管理の見直し対象となった財はかなり狭い範囲で定義されており、GTAP データベース

\footnotetext{
3 キャリブレーションの方法の概要については、細江ほか(2016, 第 5-6 章)参照。弾力性データについては 補論参照。弾力性について、異なる值を用いて本文中と同様のシミュレーションを行い、シミュレーショ ン結果の頑健性を確認した。この感応度検査の結果についても補論参照。
} 
が描写する化学産業の範囲はそれに比べると広い。また同じく、影響を受けると思われる半導体 産業は、同データベースの中では電子産業に含まれるもの、やはり、そのごく一部を構成するに 過ぎない。この問題に対処するために、GTAP データベースで区分された財・部門分割を、関税 率表で記載されるような詳細な品目別にまで、さらに分割することもモデル化の方向性として 考えられる4。しかし、現段階では政策変更の影響と大きさからして不確実な点が多いので、こ こでは簡便に GTAP の部門分割でもっとも詳細なものをそのまま用いるにとどめる。その代わ り、あらかじめこれらの間の部門分割の対応関係について確認しておくことにしよう。

表 2.1 は GTAP で定義された化学と電子産業のなかに、それぞれ韓国の産業連関表(input-output tables, IO tables)(中分類、生産者価格)(Bank of Korea (2019))で定義された部門として何がどの程度 含まれるかを示している。政策変更の対象になる 3 品目については、表 2.1 中の basic chemical products, synthetic resins and synthetic rubbers, other chemical products に該当すると思われるが、そ れであっても、これらの生産量のすべてではない。また、半導体産業については、GTAP データ ベースの電子製品(computer, electronic and optical products)分野の 29\%程度である。

\footnotetext{
${ }^{4}$ GTAP データベースで区分されたよりもより詳しい財・部門分割を施すためのツールである SplitCom を 利用して行うことができる。詳しくは、Center of Policy Studies, Victoria University のウェブサイト参照: https://www.copsmodels.com/splitcom.htm
} 
表 2.1: GTAP で定義された部門と韓国産業連関表との比較

\begin{tabular}{lrr}
\hline \multicolumn{1}{c}{ GTAP Sector/Korean IO Table Sector } & mil. KRW & $\begin{array}{c}\text { \% in GTAP } \\
\text { Sector }\end{array}$ \\
\hline Chemical (GTAP) & & \\
Basic chemical products & $63,315,419$ & 27.8 \\
Synthetic resins and synthetic rubbers & $40,175,178$ & 17.7 \\
Chemical fibers & $3,388,906$ & 1.5 \\
Fertilizers and pesticides & $4,807,758$ & 2.1 \\
Other chemical products & $38,478,475$ & 16.9 \\
Plastic products & $62,630,815$ & 27.5 \\
Rubber products & $14,737,354$ & 6.5 \\
\hline & & 100.0 \\
Computer, electronic and optical products (GTAP) & & \\
Semiconductor and related devices & $80,509,086$ & 28.5 \\
Electronic signal equipment & $65,827,406$ & 23.3 \\
Other electronic components & $23,636,299$ & 8.4 \\
Computer and peripheral equipment & $7,528,911$ & 2.7 \\
Telecommunication, video, and audio equipment & $75,333,738$ & 26.7 \\
Precision instruments & $29,378,121$ & 10.4 \\
\hline & & 100.0 \\
\hline
\end{tabular}

出典: Bank of Korea (2019) 2015 Benchmark Input-output Tables.

あわせて、韓国の半導体産業の中間投入物の構成を確認する。表 2.2 の化学製品すべてを合わ せた投入シェア(対総投入)はせいぜい 6\%であり、これだけ見れば、供給が完全に途絶しない限 り、輸出管理の厳格化は生産にあまり大きな影響を与えそうにない。電子製品部門からの投入は、 どの産業でもそうなりがちであるが、自己投入が大きく総投入の $1 / 4$ を越える。多くの中間投入 財で輸入依存度(各中間投入財について輸入中間投入が占める割合)は高く、40-80\%に達する。こ のため、輸入に滞りがでた場合には、それだけ大きく生産に影響する可能性があることを示唆す る。ただし、輸入依存度が高いとしても、日本以外の国からの輸入や国産品で代替可能性が高い 
場合には影響は小さくなるので、そうした要因も考慮する必要がある。

表 2.2: 半導体産業の化学製品と電子製品の中間投入

\begin{tabular}{|c|c|c|c|c|}
\hline \multirow[b]{2}{*}{ Korean IO Sector } & \multicolumn{2}{|c|}{ Input } & \multicolumn{2}{|c|}{ Imported Input } \\
\hline & mil. KRW & $\begin{array}{l}\% \text { of Total } \\
\text { Input }\end{array}$ & mil. KRW & $\begin{array}{l}\% \text { of } \\
\text { Input }\end{array}$ \\
\hline Basic chemical products & $1,413,163$ & 1.8 & 935,850 & 66.2 \\
\hline Synthetic resins and synthetic rubbers & 605,789 & 0.8 & 375,469 & 62.0 \\
\hline Chemical fibers & 0 & 0.0 & 0 & - \\
\hline Fertilizers and pesticides & 12,865 & 0.0 & 527 & 4.1 \\
\hline Other chemical products & $2,892,236$ & 3.6 & $2,247,059$ & 77.7 \\
\hline Plastic products & $1,348,876$ & 1.7 & 666,127 & 49.4 \\
\hline Rubber products & 12,725 & 0.0 & 5,106 & 40.1 \\
\hline$\ldots$ & & & & \\
\hline Semiconductor and related devices & $21,153,671$ & 26.3 & $12,810,965$ & 60.6 \\
\hline Electronic signal equipment & 3,719 & 0.0 & 1,749 & 47.0 \\
\hline Other electronic components & $3,255,321$ & 4.0 & 867,005 & 26.6 \\
\hline Computer and peripheral equipment & 3,161 & 0.0 & 1,518 & 48.0 \\
\hline $\begin{array}{l}\text { Telecommunication, video, and audio } \\
\text { equipment }\end{array}$ & 49,456 & 0.1 & 9,619 & 19.4 \\
\hline Precision instruments & 97,271 & 0.1 & 59,595 & 61.3 \\
\hline
\end{tabular}

出典: Bank of Korea (2019) 2015 Benchmark Input-output Tables.

3. シミュレーション

3.12 つのシミュレーション・シナリオ

輸出管理厳格化の直接的な影響がどのようなものになるのかは、必ずしも明らかではない。そ こで、以下の 2 種類のシナリオを考える。まず、輸出管理厳格化を貿易障壁と捉えるならば、日 本から韓国へ輸出する際に輸出税が課されるという形で理解できる。これを「輸出税シナリオ」 と呼ぼう。 
あるいは、たとえ結果的に必要な輸入中間投入財を手に入れられたとしても、韓国の半導体生 産者側で生産性が低下することも考元られる。たとえば、万一の事態に備えて代替的な輸入手段 を手配したり、より多くの在庫を抱えたりすることが考えられる。あるいは、こうした輸入中間 財の入手可能性について不確実性が高まれば生産計画が立てにくくなり、以前よりも低い生産 量を想定することになるかもしれない。そうした影響は、半導体生産者の生産関数の TFP の低 下として表現できるであろう。これを「TFP シナリオ」と呼ぼう。どちらのタイプの直接的影響 が出るかは予測しがたいので、本研究では両方の影響を個別にシナリオとして考慮する。

何らかの影響が出るとしても、しかし、どの程度の影響が出るかは事前に予測することは困難 である。実際のデータがあれば、貿易障壁については重力モデル等を用いて関税率相当の障壁を 計測し、生産性については生産関数を推定してソロー残差とその変化を測ることができるが、事 前には計測できない。そこでここでは、仮の值として、輸出税シナリオでは $50 \%$ の輸出税率が日

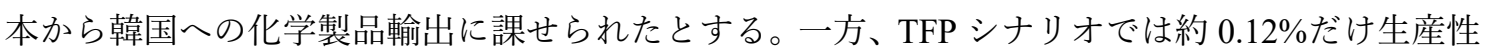
が低下したと仮定する。この值は、輸出税シナリオと同じだけの生産量の低下を、韓国の電子産 業にもたらすように逆算して得た值である5。ゆえに、どちらのシナリオを解いても、韓国の電 子産業の生産量自体は同じ影響を受ける。しかし、ほかの側面でさまざまな異なった影響を与え ることが、つぎに示すシミュレーションの結果から明らかにされる。

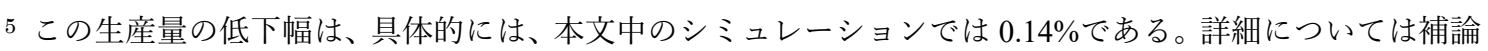
参照。
} 
日本と韓国における産業別の生産量を見る(図 3.1)。まず韓国では、どちらのシナリオでも、電 子製品部門の生産が $0.14 \%$ 減少する(ように TFP 低下幅を調整してある)。輸出税シナリオでは、 日本からの化学製品の輸入が滞るので、これを補うために国内の化学製品の生産が増加する。そ れと産業連関の強い、石油・石炭製品部門が生産を伸ばす。また、電子製品との産業連関の効果 を受けて、機械部門がそれと同程度伸びる。そのほかの産業への波及効果はあまり大きくない。

日本が受ける影響は、韓国における影響の鏡映しになっている。すなわち、化学製品の輸出が 滞るので、国内生産は減少する。ただし、国内供給がだぶつくので、それが国内の電子製品の生 産を押し上げる。あとで示すように、韓国がこの部門の輸出を減少させ、その隙間を埋めるよう に日本が輸出を拡大する。この効果も加わって、日本の国内生産がいっそう増加する。輸出税シ ナリオとは違って、TFP シナリオでは日韓ともに、一般に影響はかなり小さい。

図 3.1: 国内生産量の変化

[基準均衡からの変化率, \%]

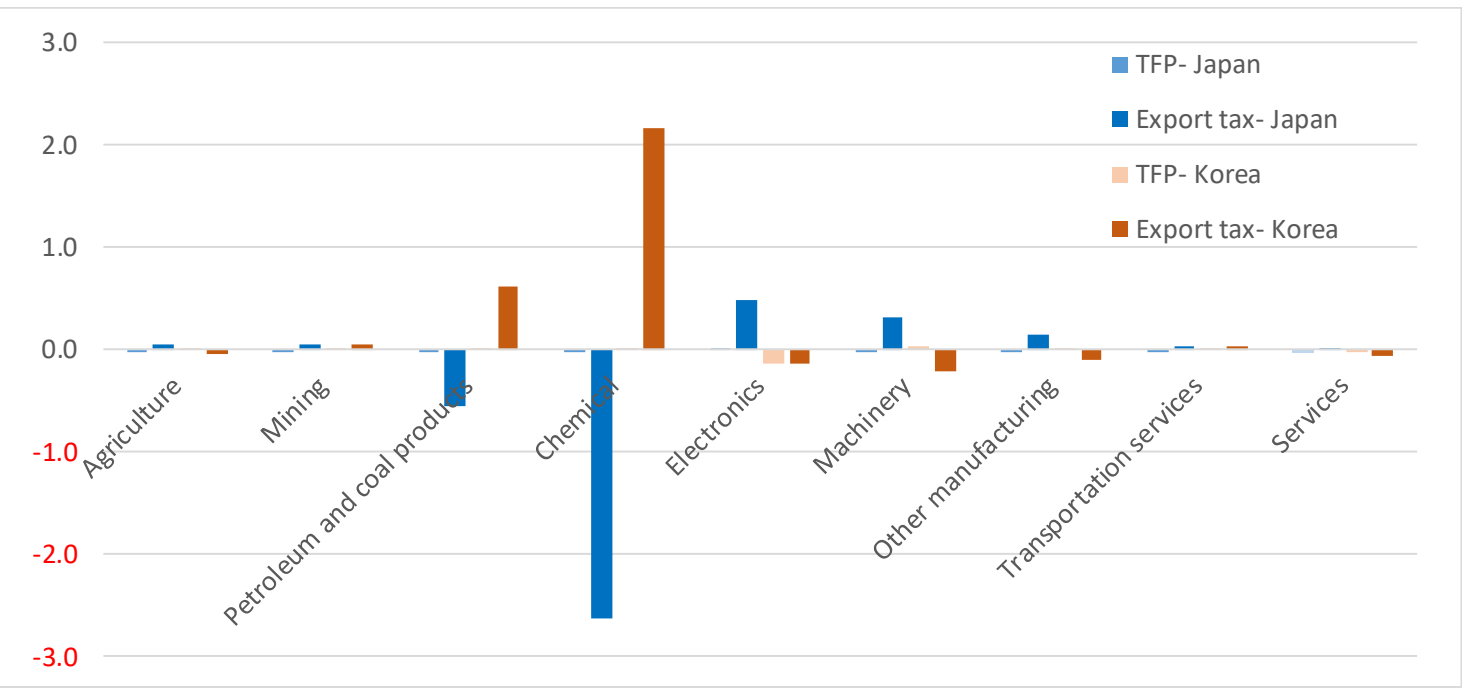


各国による電子製品輸出額の変化を見る(図 3.2)。TFP シナリオでは、韓国は生産性の低下に よって国内供給力を言失した分、輸出にも直ちにその影響が現れ、262 百万米ドルだけ輸出を減 らす。この国際市場における供給不足を、日本をはじめとする主要 5 地域が埋める。

図 3.2:【TFP シナリオ】各国による電子製品輸出額の変化と仕向地別内訳 [単位: 百万 USD]

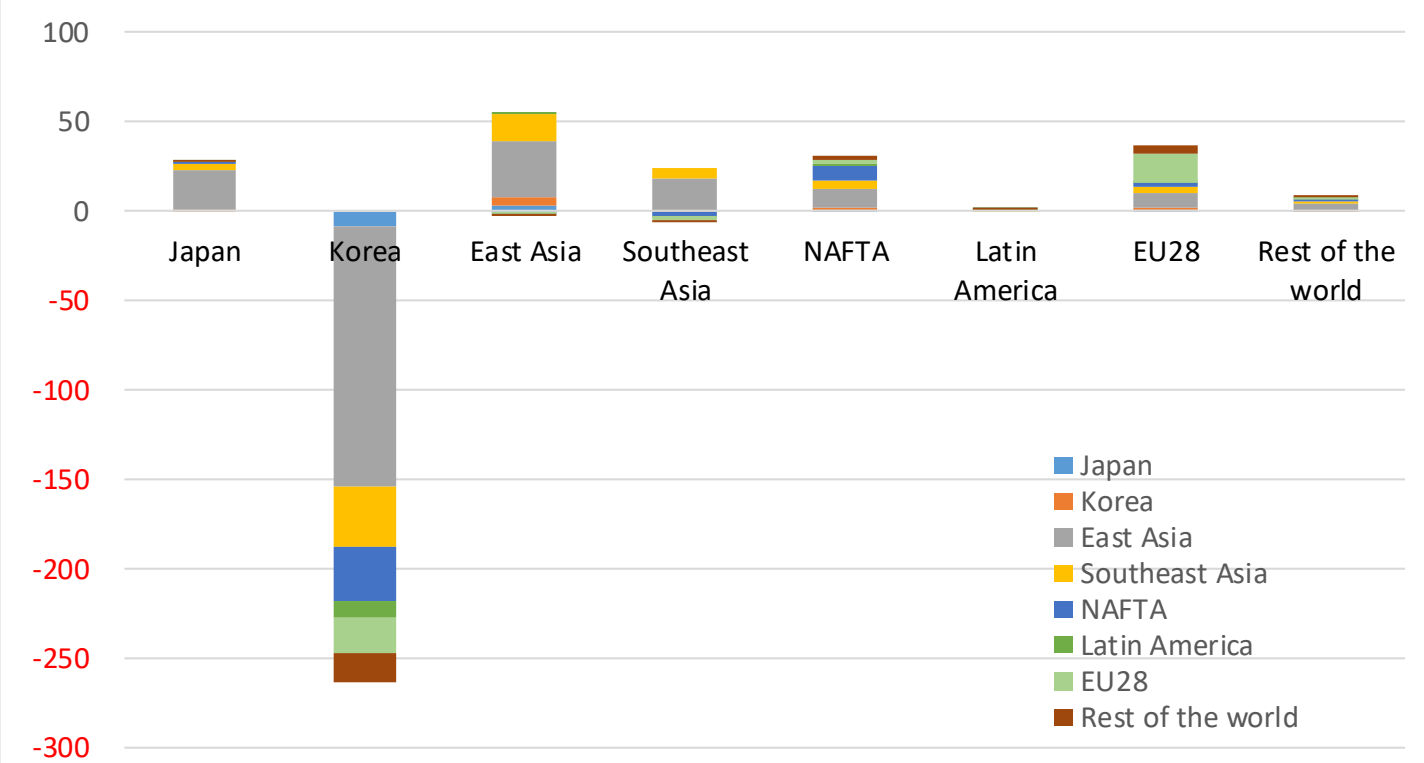

注：輸出額はラスパイレス価格(政策変更前の価格)で評価・集計している

一方、輸出税シナリオの場合には、大きく違った結果が出てくる。韓国が輸出を減少させる点 は同じであるが、その大きさは 174 百万 USD までに減少する。くわえて、東アジア、東南アジ ア、NAFTA、EU28 も同程度ないしそれ以上に輸出を減少させる。背景にあるのは、日本による 輸出の大きな伸びである。韓国に輸出せずにだぶついた化学製品を電子製品の国内生産に回し、 これが世界市場に大きく流れ込む。 
図 3.3: 【輸出税シナリオ】各国による電子製品輸出額の変化と仕向地別内訳 [単位: 百万 USD]

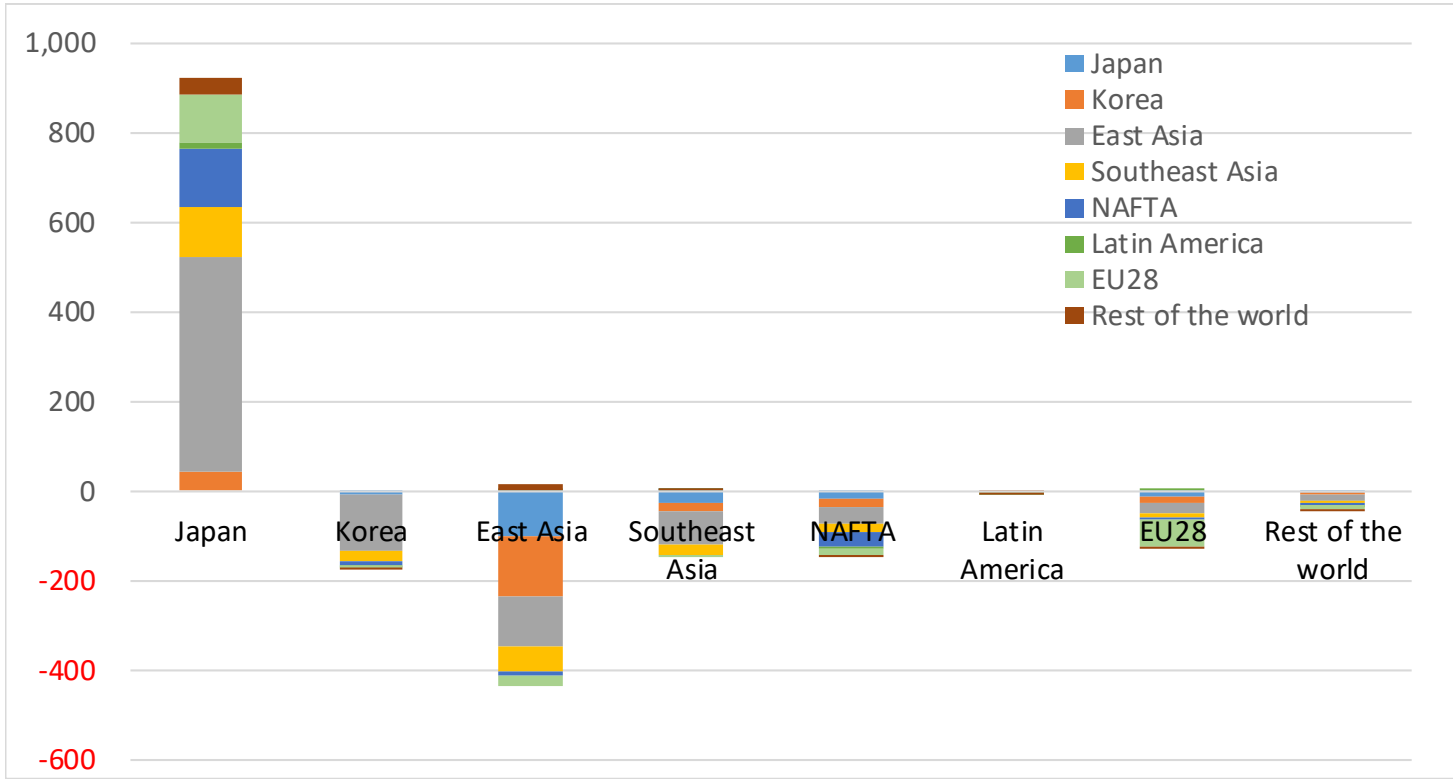

注：輸出額はラスパイレス価格(政策変更前の価格)で評価・集計している

同じ貿易量の変化を、今度は輸入側から見る(図 3.4)。韓国の半導体輸出に大きく依存する世 界経済は、輸出管理の厳格化によってその供給が途絶えることを大きく懸念している。TFP シナ リオでは、実際、韓国からの輸入供給は大幅に落ち込んでいる。しかしその不足分のいくらかは、 ほかの地域からの輸入で補うことができている。この追加的な供給は、失われた韓国からの供給 のうち、NAFTA 地域で 29\%、EU28 で 77\%、東アジアで 67\%を埋め合わせている。東南アジア に至っては韓国の TFP 低下前と同じだけの輸入を確保できており、地域ごとに違いがある。 
図 3.4: 【TFP シナリオ】各国による電子製品輸入額の変化と供給地別内訳 [単位: 百万 USD]

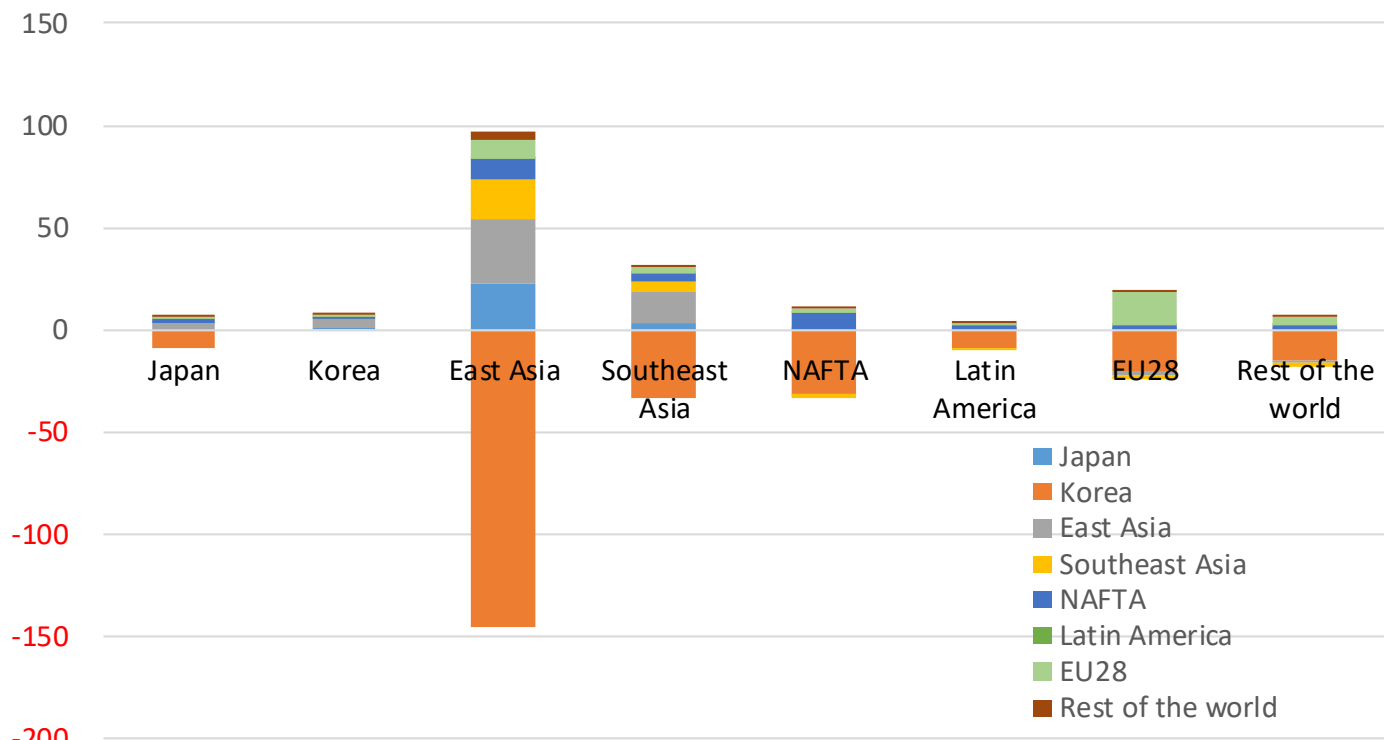

注：輸入額はラスパイレス価格(政策変更前の価格)で評価・集計している

輸出税シナリオの場合は、日本からの供給が、失われた韓国からの供給だけでなく、その他の 主要な地域からの輸入をも代替する(図 3.5)。日本と韓国以外の地域では、総輸入量は政策変更 までとほとんど代わらないか、あるいは、それよりも多くなっている。 
図 3.5:【輸出税シナリオ】各国による電子製品輸入額の変化と供給地別内訳 [単位: 百万 USD]

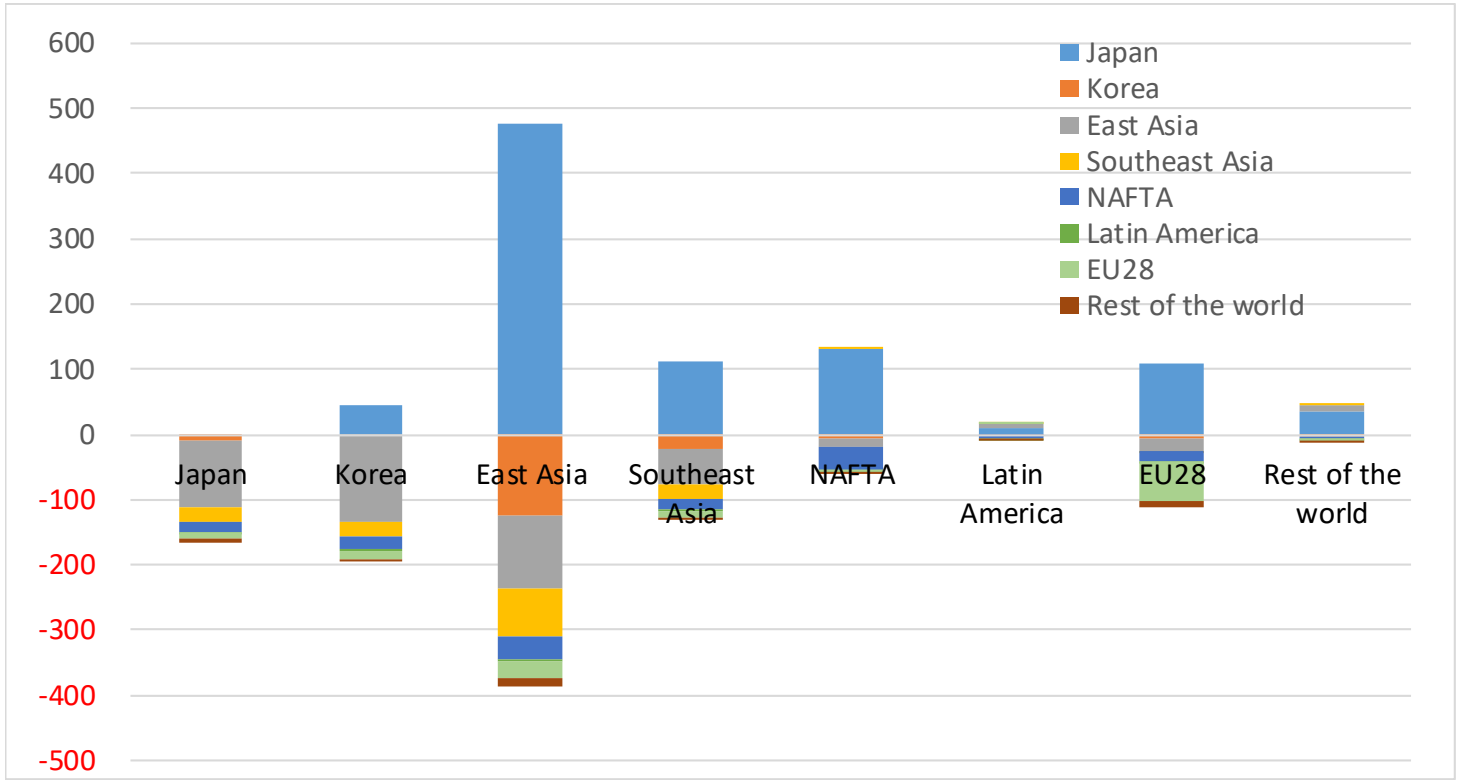

注：輸入額はラスパイレス価格(政策変更前の価格)で評価・集計している

図 3.6 に消費者側の影響を等価変分(実質消費の変化)で測った経済厚生の変化を示す。TFP シ

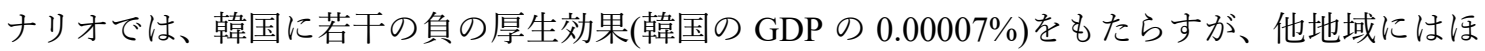
とんど厚生上の影響を与えない。輸出税シナリオは、それより明らかに大きな変化をもたらす。 韓国が被る悪影響が最も大きいことは当然としても、日本のそれも大体同じ程度である。高率の 輸出税によって貿易に歪みが生じ、その損失が大きく影響しているものと考えられる。実際、輸 出入が、質的にも量的にも TFP シナリオの場合よりも大きく影響を受けている。ただし、両国 の経済規模の違いを調整するために対 GDP 比で見ると、韓国が被る悪影響は GDP の $0.00152 \%$ 、 日本のそれは GDP の $0.00034 \%$ にどまる。日韓以外の国々は、日本による安価な電子製品輸出 を通じて、若干ではあるが厚生が改善する(GDP の 0.0001\%以下)。 
図 3.6: 経済厚生効果

[等価変分, 百万 USD]

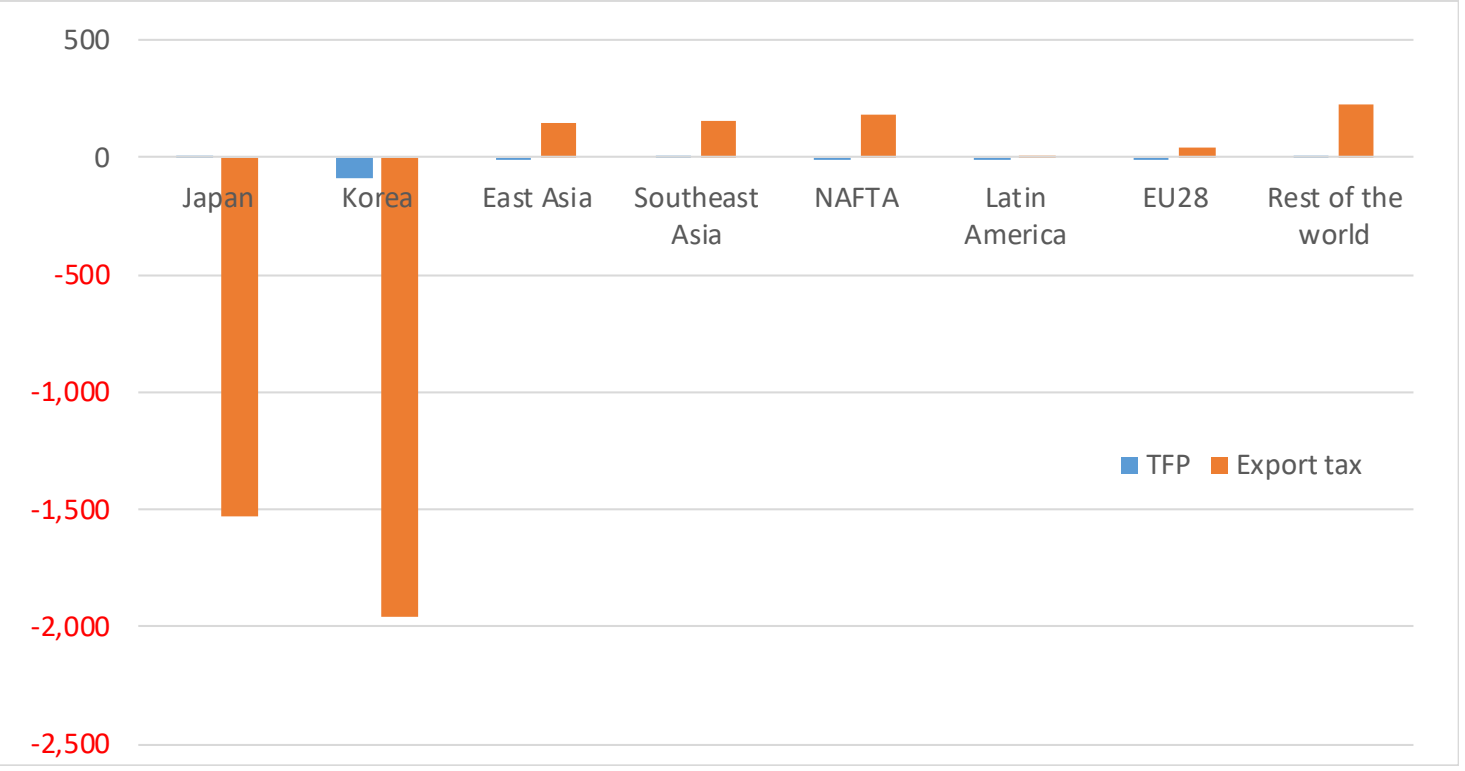

\section{4. 結語}

本研究では、日本が行う予定の半導体関連原料に対する対韓輸出管理の厳格化の影響を、応用 一般均衡モデルによって分析した。質的・量的に状況が大いに流動的であるため、直接的影響と して輸出税が課されると考える場合、韓国国内の電子製品の生産性が低下する場合の 2 種類を 考え、それぞれについて日韓経済、および、電子製品の世界市場に与える影響を示した。輸出税 率にして 50\%相当という仮定は、いうまでもなく、例示のために考慮した影響幅であり、貿易障 壁はこれより大きくも、小さくもなり得る。分析上、比較が容易になるように、これと同等の影 響をもたらすような生産性低下幅を韓国の電子製品産業について仮定したが、これら 2 種類の 直接的影響の必ずどちらかだけが発生するとも限らない。両方の形の悪影響が同時に発生する こともありえる。こうしたいくつもの点で、本研究のシミュレーション結果とその解釈には一定 の留保が必要である。 
こうしたいくつもの不確実性があるとしても、輸出管理の厳格化の影響について、とくに質的 な観点からいくつかの指摘が可能であろう。輸出管理の厳格化が、韓国の電子製品産業の生産性 を引き下げるという形で影響を発生させるとするならば、悪影響は規模と範囲の両方について 限定的なものにとどまる。ましてや、世界的な供給不安に結びつくものではないであろう。また、 輸出税率にして $50 \%$ という大きなショックを受けたとしても、韓国の電子製品生産量は $0.14 \%$ 程 度しか減らない、という点は注目に值する。ただし、それ以外の側面では、輸出管理の厳格化が、 (禁輸措置とはほど遠いにせよ)具体的な輸出規制の形を取ることで、その影響はより大きく、ま た、より広い範囲におよぶことが予想される。すなわち、韓国だけにとどまらず、日本の化学産 業や、消費者全体の大きな不利益につながる。ただし、経済規模が違うこともあって、悪影響の 程度は韓国が受けるほど大きくはないであろう。したがって、現在考兄られている程度の政策変 更の程度と範囲を前提とする限りは、自国が受ける悪影響を懸念するという動機で輸出管理の 厳格化を日本がためらう理由は大きくないと考元られよう。

最後に、本研究の限界と将来的な展開の可能性について述べて結語とする。繰り返し注釈を付 しているように、輸出管理の厳格化の直接的な影響経路とその具体的な大きさについては、なん ら予測を行った上で分析に取り込んだわけではない。本事案について実際に事象が発生するか、 類似事案についてデータの裏付けのある研究をして初めて、こうしたシナリオの妥当性につい て検証できる。シナリオの問題とは別に、ここで問題になった化学製品 3 品目のように、関税表 に出てくるような詳細な品目について検討したい場合に、GTAP データベースを用いた比較的粗 い財・部門分割のモデルを用いると、直接的な影響範囲については過大な範囲を考えることにな ってしまう。CES/CET 関数における財や地域間の代替/変形の弾力性も、応用一般均衡モデル分 
析の常として確認が必要になるであろう。

政策分析上は、今般の日本政府の措置が、必ずしも当該 3 品目に対する輸出管理の問題にとど まらない可能性があることが重要な点である。実際、これが韓国政府の懸念事項であろう。輸出 管理厳格化の対象範囲を広げた場合の影響についても、こうした応用一般均衡分析によって示 唆を得ることができる。ここではなるべく単純な形で、資本が部門間を移動せず、また、国境を 越えるようなことはないとして、短期的な状況を前提にして影響分析を行った。韓国の半導体産 業が多くの海外直接投資を受け入れていることを考えれば、Hosoe (2014)が行ったような、2 国 間の海外直接投資を考慮した分析も、より長期的な影響を測るために有用であろう。 


\section{参考文献}

Armington, P. (1969) “A Theory of Demand for Products Distinguished by Place of Production," IMF Staff Paper 16: 159-178.

Bank of Korea (2019) 2015 Benchmark Input-output Tables, March.

Dhingra, S., Huang, H., Ottaviano, G., Pessoa, J. P., Sampson, T., Van Reenen, J. (2017) “The Costs and Benefits of Leaving the EU: Trade Effects," Economic Policy 32: 651-705.

Hertel, T .W. (1997) Global Trade Analysis: Modeling and Applications, Cambridge University Press.

Hosoe, N. (2004) “Crop Failure, Price Regulation, and Emergency Imports of Japan's Rice Sector in 1993,” Applied Economics 36: 1051-1056.

Hosoe, N. (2014) “Japanese Manufacturing Facing Post-Fukushima Power Crisis: a Dynamic Computable General Equilibrium Analysis with Foreign Direct Investment," Applied Economics 46: 20102020.

Hosoe, N. (2018) "Impact of Border Barriers, Returning Migrants, and Trade Diversion in Brexit: Firm Exit and Loss of Variety," Economic Modelling 69: 193-204.

Jafari, Y., Britz, W. (2018) "Brexit: an Economy-wide Impact Assessment on Trade, Immigration, and Foreign Direct Investment," Empirica 46: 1-16.

PwC (2016) "Leaving the EU: Implications for the UK Economy," March. https://www.pwc.co.uk/economic-services/assets/leaving-the-eu-implications-for-the-ukeconomy.pdf (2019 年 7 月 27 日アクセス).

Yang, H., Park, J.-M. (2019) “Japan-South Korea Gloom Spurs Worries of 'Never Seen before' Chip Price Spike,” Reuters, July 18. https://www.reuters.com/article/us-southkorea-japan-laborers-chipsanaly/japan-south-korea-gloom-spurs-worries-of-never-seen-before-chip-price-spikeidUSKCN1UD0ZL (2019 年 7 月 28 日アクセス).

川㠃研一 (2017)「台頭する地域統合の不確実性-代替的な地域貿易協定シナリオの経済効果-」, GRIPS Discussion Paper 16-27. 
経済産業省 (2019)「大韓民国向け輸出管理の運用の見直しについて」，7月 1 日. https://www.meti.go.jp/press/2019/07/20190701006/20190701006.html (2019 年 7 月 6 日アク セス)

ニューズウィーク日本版 (2019)「日本の輸出規制で半導体価格が上昇 日韓対立に市場は『前例 なき急騰』警戒」, 7 月 3 日. https://www.newsweekjapan.jp/stories/business/2019/07/post12599.php (2019 年 7 月 6 日アクセス)

細江宣裕, 我澤賢之, 橋本日出男 (2016)『テキストブック応用一般均衡モデリング: プログラム からシミュレーションまで 第 2 版』, 東京大学出版会. 


\section{補論}

\section{A.1 感応度検査}

本研究で行われたシミュレーション結果は、ほかのモデルを用いた研究と同様、モデルの中の いくつかの仮定に基づいている。とくに、応用一般均衡モデル分析では、財間の代替の弾力性に 大きく依存することが知られている。ここでは、(1)輸入財と国内財との間の Armington (1969)の

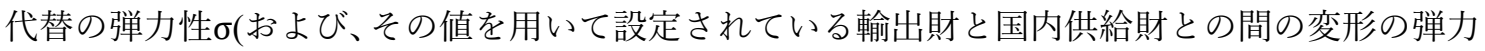
性、各国からの輸入財間の代替の弾力性、および、各国への輸出財間の変形の弾力性)と、(2)生 産要素間の代替の弾力性 $\sigma^{\mathrm{VA}}$ を変化させたときに、どの程度結果が質的・量的に影響を受けるか を確認する感応度検査を行う。化学製品と電子製品産業について、本文で仮定した弾力性(表 A.1) の 2 倍、ないし、0.5 倍の值を仮定して、50\%の輸出税率を課すシミュレーションを同じように 行う(輸出税シナリオ)。

ただし、仮定された弾力性が異なれば、同じだけの輸出税を課したとしても韓国の電子製品産 業が被る生産量減少幅が異なる。そこで、TFP シナリオについては、輸出税シナリオの結果と比 較可能にするために、TFP の低下率はそれぞれ異なったものを仮定する(表 A.2)。このため、輸 出税シナリオの結果については相互に比較可能であるが、TFP シナリオ間でその結果を比較す る際には注意が必要である。 
表 A.1： 本文中のシミュレーションで用いられた代替の弾力性

\begin{tabular}{lcc}
\hline & Armington $\sigma$ & Factor Input $\sigma^{\mathrm{VA}}$ \\
\hline Agriculture & 2.35 & 0.25 \\
Mining & 5.70 & 0.20 \\
Petroleum and coal products & 2.10 & 1.26 \\
Chemical & 3.30 & 1.26 \\
Electronics & 4.40 & 1.26 \\
Machinery & 3.54 & 1.26 \\
Other manufacturing & 3.26 & 1.23 \\
Transportation services & 1.90 & 1.68 \\
Other services & 1.95 & 1.36 \\
\hline
\end{tabular}

出典: GTAP データベース・バージョン 10

注: すべての国について同じ弾力性を仮定する

表 A.2: TFP シナリオ中で仮定された TFP 低下幅

Assumed TFP Change [\%]

Output Change [\%]

\begin{tabular}{lll}
\hline Base & -0.065 & -0.137 \\
$\sigma \times 2$ & -0.064 & -0.151 \\
$\sigma \times 0.5$ & -0.034 & -0.061 \\
$\sigma^{\mathrm{VA}} \times 2$ & -0.095 & -0.261 \\
$\sigma^{\mathrm{VA}} \times 0.5$ & -0.036 & -0.059 \\
\hline
\end{tabular}

注: 基本シミュレーション(base)における TFP 低下幅は、日本から韓国への化学製品に輸出税 $50 \%$ が課されたときに、韓国の電子製品産業が被る生産量低下幅 $(0.137 \%)$ を再現するだけの大 きさに設定されている。

一連のシミュレーションにより、弾力性に一定の幅を持たせたとしても、生産量(図 A.1)や輸 出量(図 A.2)、輸入量(図 A.3)が受ける影響は定性的には変わらない。厚生効果(図 A.4)について もおおむね質的に変化はない。一般的に、弾力性が大きいほど貿易量が受ける影響は大きくなる が、国内生産や厚生への影響は単純ではない。これは、弾力性が大きいほどこれらの変数が強い 反応を示す一方で、経済全体としてはより柔軟にショックを吸収することができるためである。 
図 A.1：国内生産量の変化:

[基準均衡からの変化率, \%]

- 日本

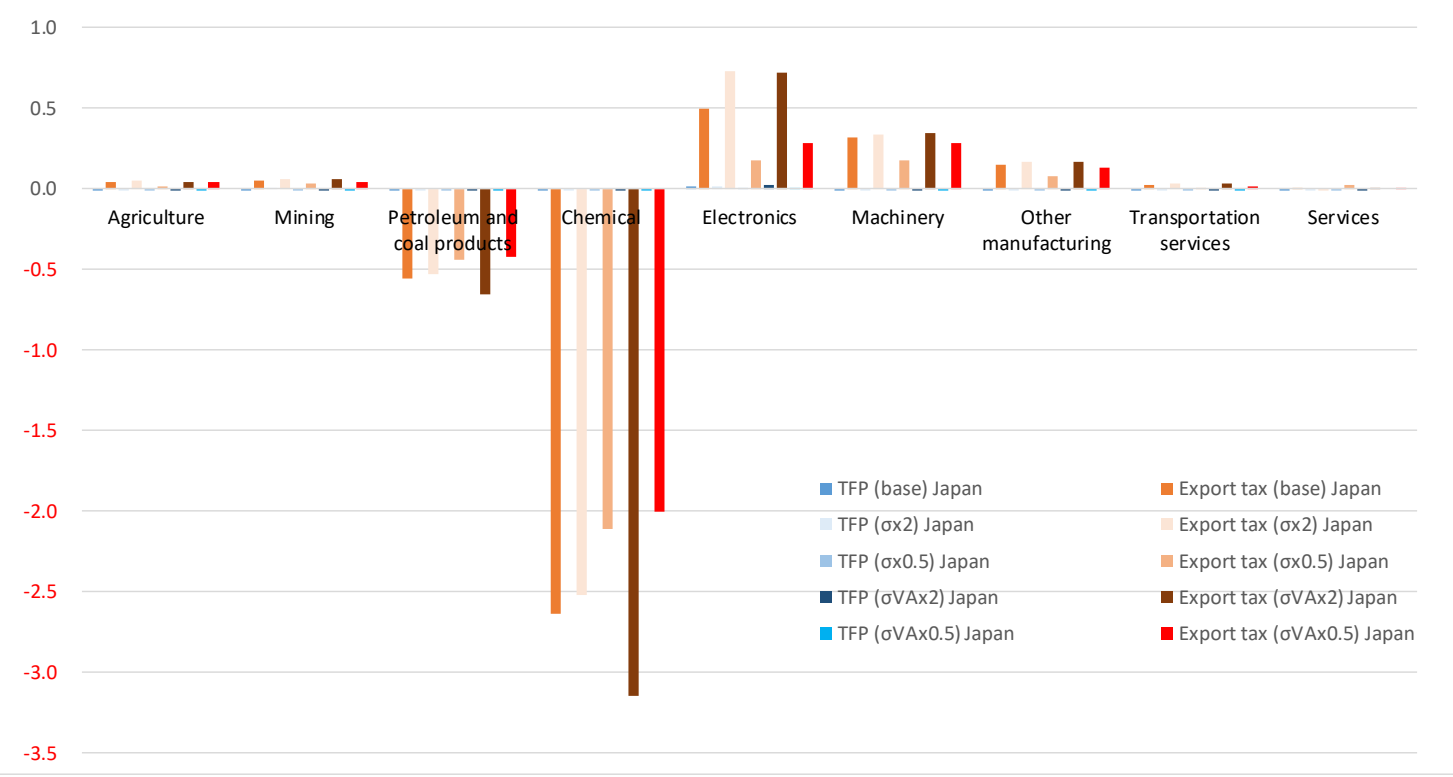

- 韓国

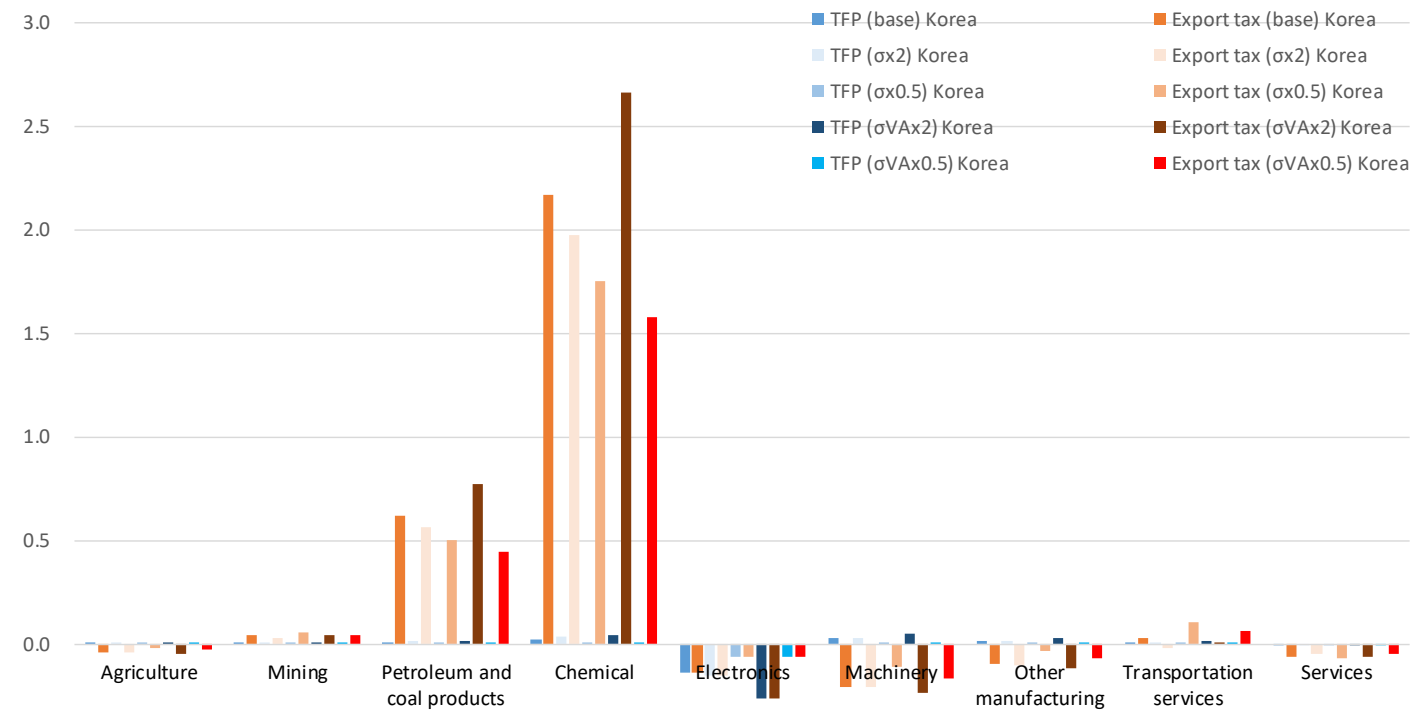


図 A.2: 各国による電子製品輸出額の変化と仕向地別内訳 [単位: 百万 USD]

【輸出税シナリオ】

- Armington の代替の弾力性 2 倍

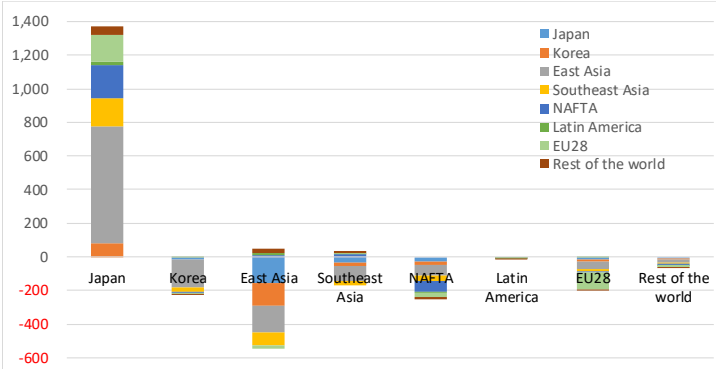

· Armington の代替の弾力性 0.5 倍

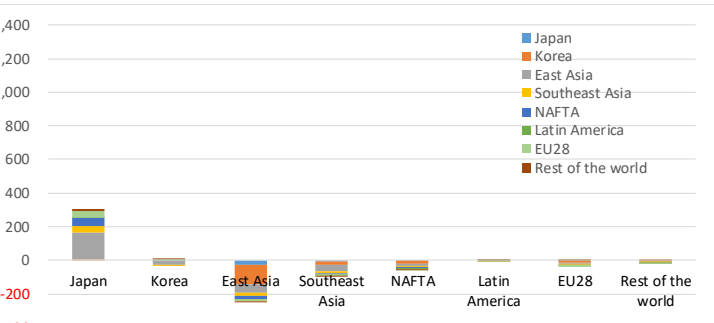

・生産要素間の代替の弾力性 2 倍

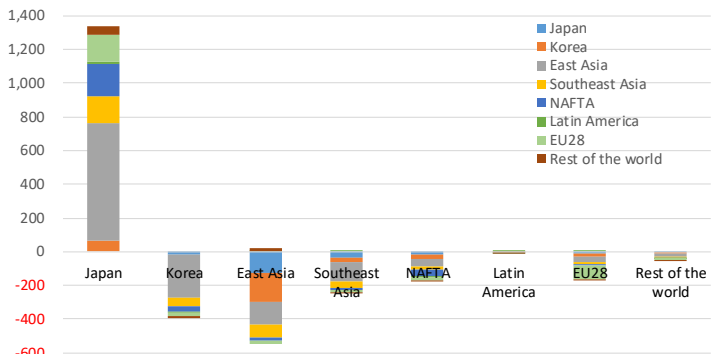

$-800$

・生産要素間の代替の弾力性 0.5 倍

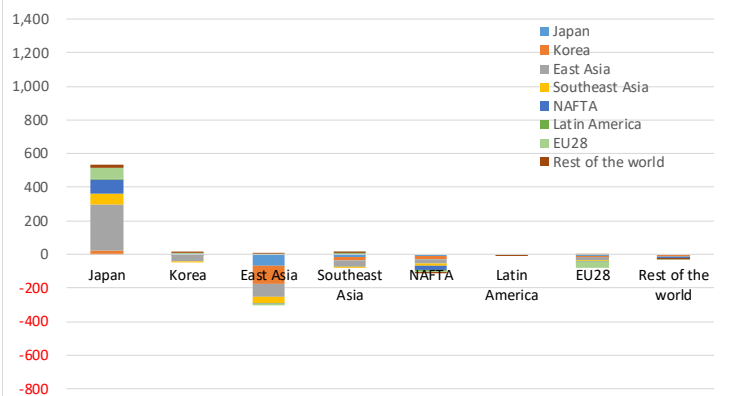

\section{【TFP シナリオ】}
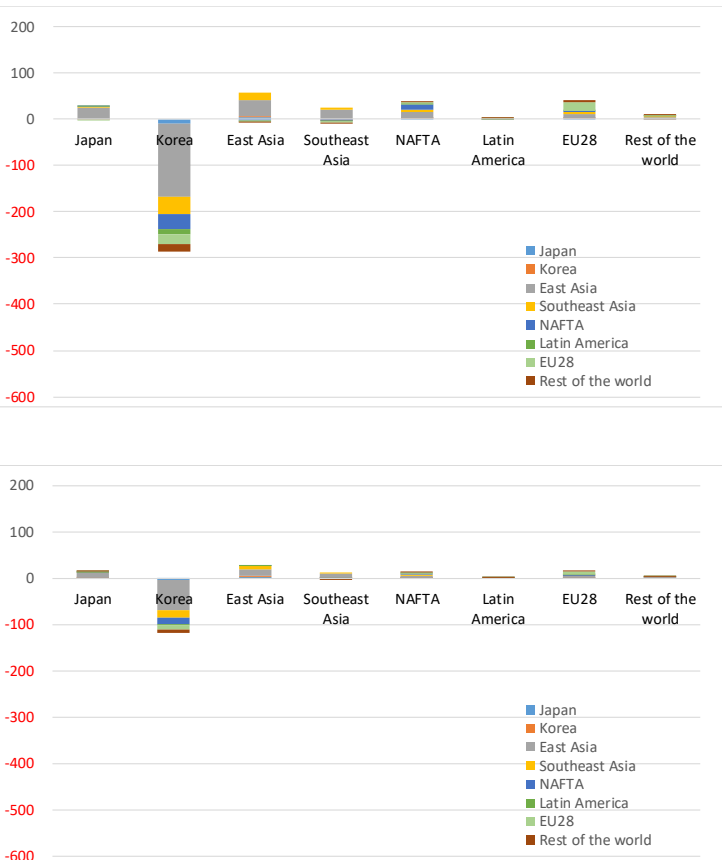

$-600$

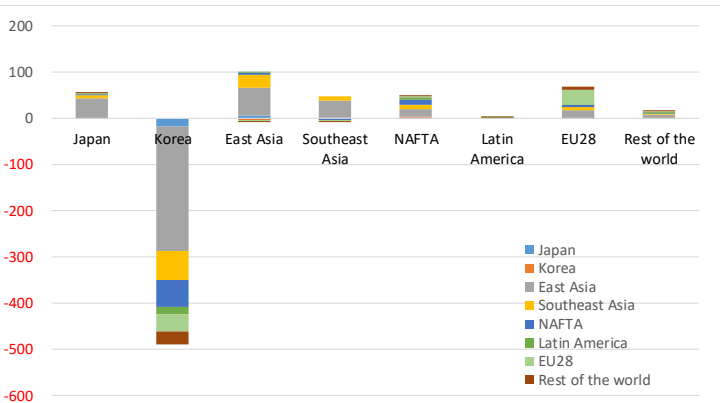

$-600$

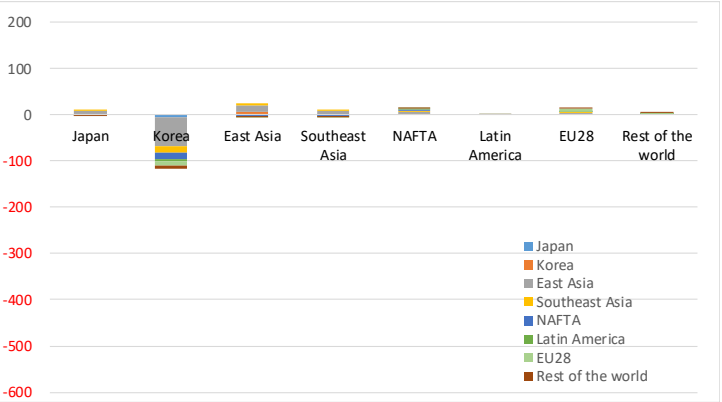


図 A.3: 各国による電子製品輸入額の変化と供給地別内訳 [単位: 百万 USD]

【輸出税シナリオ】

・Armington の代替の弾力性 2 倍
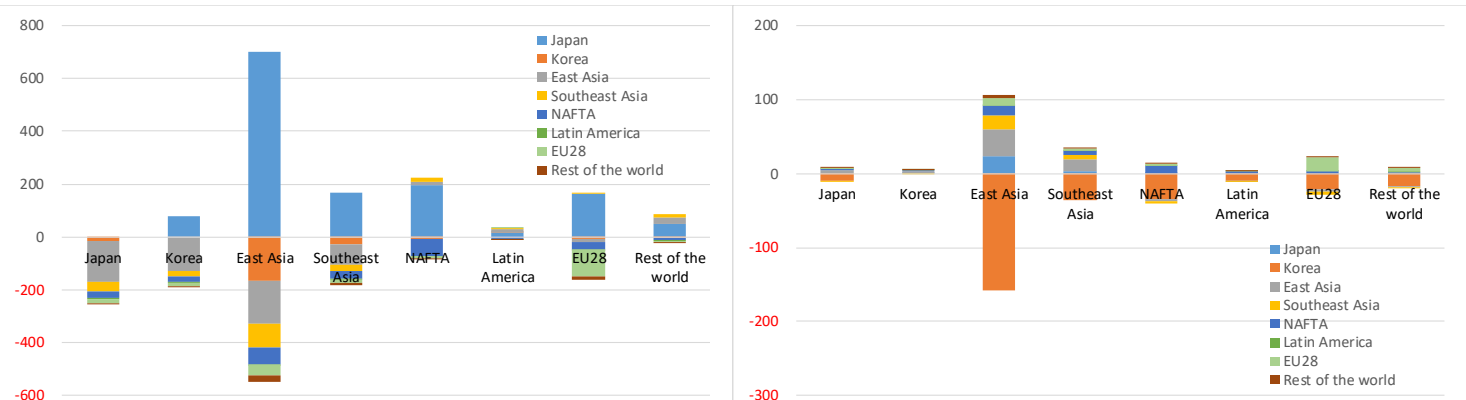

· Armington の代替の弾力性 0.5 倍
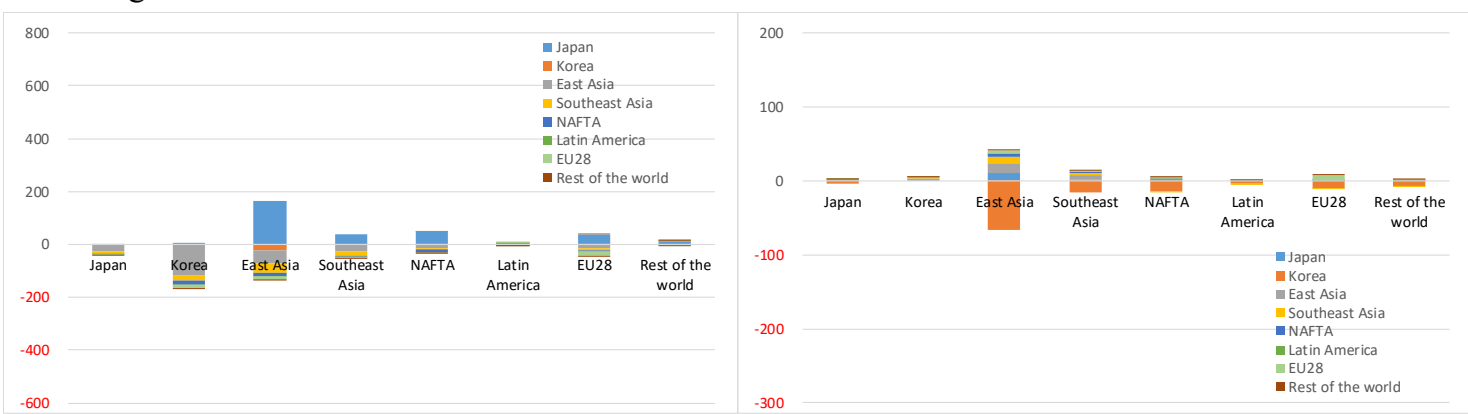

・生産要素間の代替の弾力性 2 倍

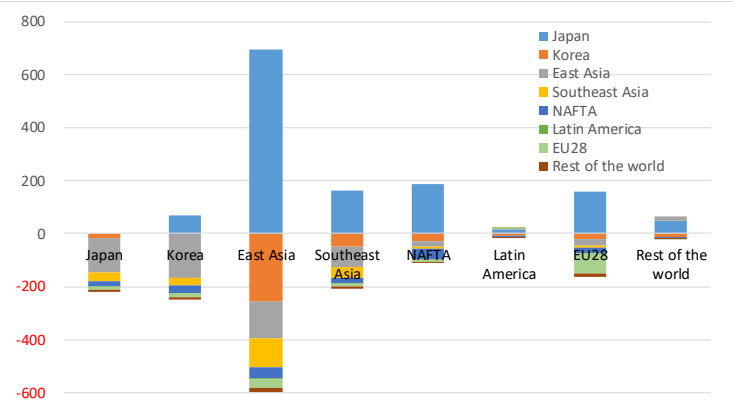

・生産要素間の代替の弾力性 0.5 倍

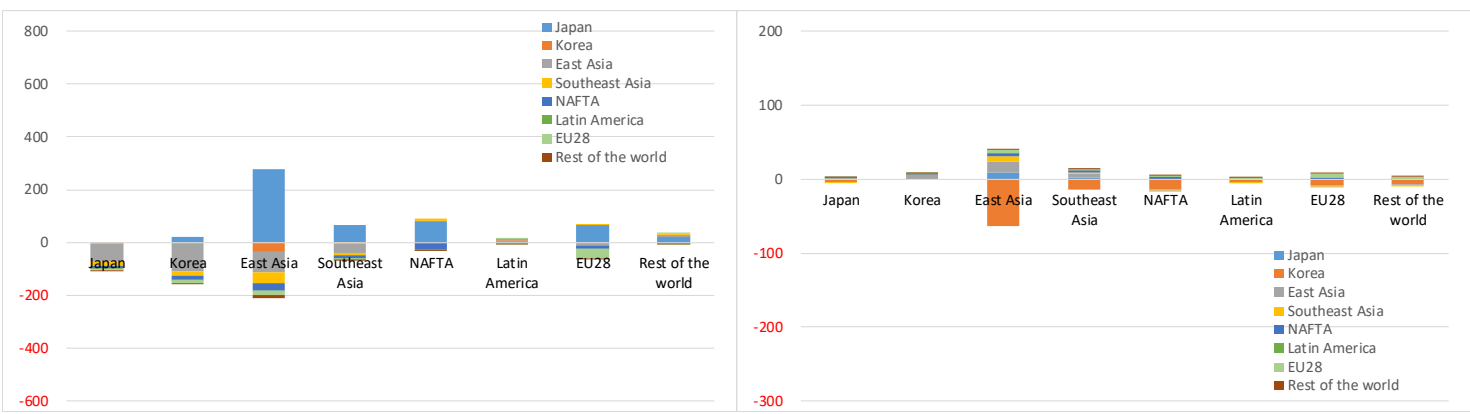


図 A.4: 経済厚生効果

[等価変分, 百万 USD]

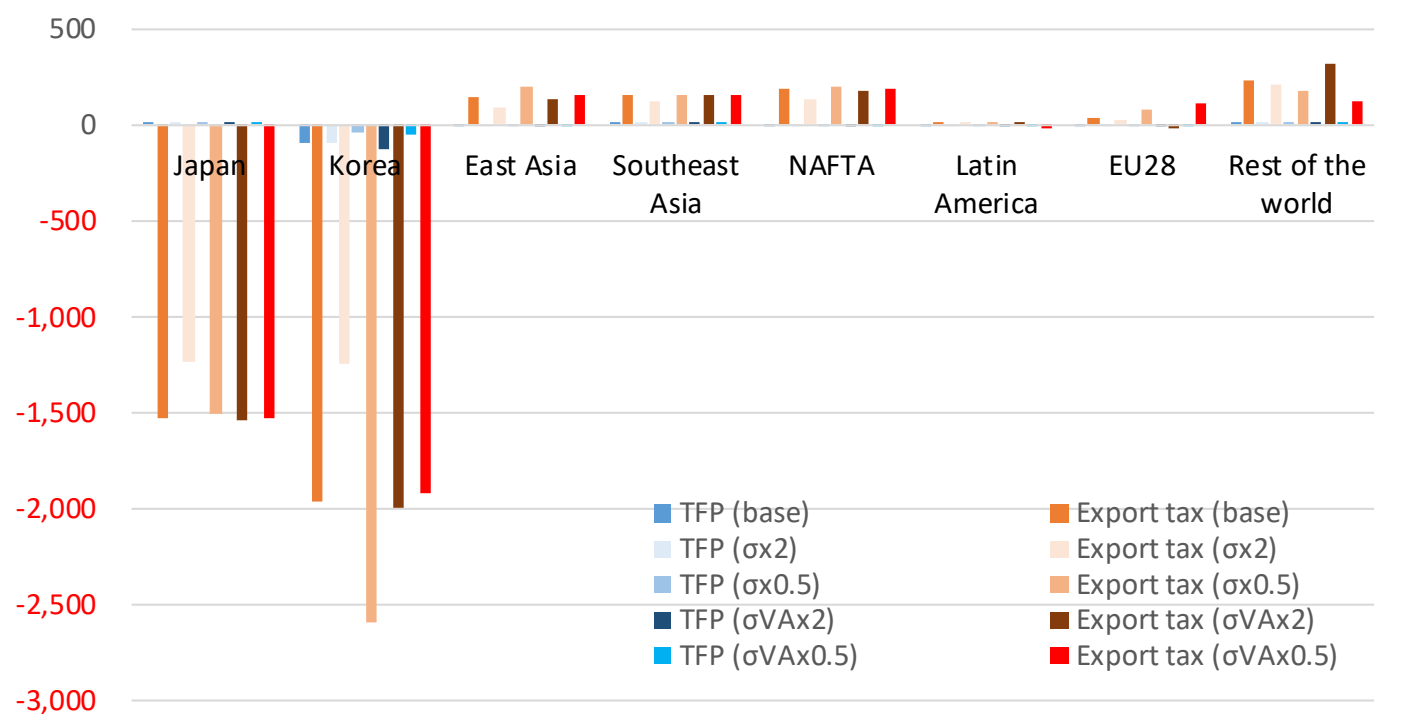

\section{A.2 GTAP 部門の集計}

\begin{tabular}{ll}
\hline Sector & GTAP Sector Abbreviation \\
\hline Agriculture & prd, wht, gro, v_f, osd, c_b, pfb, ocr, ctl, oap, rmk, wol, frs, fsh \\
Mining & coa, oil, gas, oxt \\
Petroleum and coal products & p_c \\
Chemical & chm, rpp \\
Electronics & ele \\
Machinery & ome, mvh, otn \\
Other manufacturing & cmt, omt, vol, mil, pcr, sgr, ofd, b_t, tex, wap, lea, lum, ppp, bph, nmm, \\
Transportation services & i_s, nfm, fmp, eeq, omf \\
Other services & ely, wtp, atp \\
Factor & dwe \\
\hline Skilled labor & GTAP Factor Abbreviation \\
Unskilled labor & tech_aspros, clerks, off_mgr_prs \\
Capital & service_shop, ag_othlowsk \\
\hline
\end{tabular}




\title{
Impact of Tighter Controls on Japanese Chemical Exports to Korea
}

August 20, 2019

Nobuhiro Hosoe

National Graduate Institute for Policy Studies

\begin{abstract}
The Japanese Ministry of Economy, Trade and Industry announced recently that they will terminate preferential treatment in the licensing of specific chemical products for export to South Korea. This announcement evoked concern that the impact on Korean semiconductor and electronics industries, which rely heavily on imports from Japan, might cause a serious supply shortage in the global semiconductor market. To assess the economic impact of tighter export controls, this study simulates: (a) imposition of an export tax on chemical products; and (b) a productivity decline in the electronics sector in Korea, using a world trade computable general equilibrium model. The results of these simulations indicate that such a productivity decline would cause only slight harm to the Japanese and world economies, aside from the electronics sector in Korea, and that an export tax would significantly distort trade patterns and undermine the welfare of Japan and Korea in a similar magnitude. However, welfare loss normalized for GDP size would be far smaller in Japan than in Korea.
\end{abstract}

\section{Keywords}

Trade facilitation; economic integration; computable general equilibrium analysis

JEL Classification: F13, F15, F17, C68 